\title{
Capital formation in Latin America: one and a half century of macroeconomic dynamics
}

\author{
Xavier Tafunell
}

ABSTRACT

\begin{abstract}
Macroeconomic studies indicate that physical capital formation has played a pivotal role in long-term economic growth. These studies have been hampered, however, by a data constraint: in order to pinpoint exactly what the role of capital formation has been, a larger empirical database -larger in terms of both the time span and the geographical area covered- is needed. This study addresses that problem by providing new and very extensive series on capital formation in Latin America. It also describes the different series used to identify long, medium and short-term movements. One of the outstanding features of these investment trends were their marked instability up to 1950. Another salient aspect has been the more robust growth in investment seen in the second half of the nineteenth century, which actually outdistanced the growth spurt that occurred during the "golden age" of 1950-1980.
\end{abstract} statistics, Latin America 


\section{I}

\section{Introduction}

Economic historians and specialists in the macroeconomics of development are continually trying to identify the explanatory forces behind long-term growth. Ever since the time of the classical economists, the idea that physical capital formation is one of the determinants of growth has been in the air. Economists who have sought to analyse this question empirically have used one of two approaches: growth regressions or growth accounting. The vast number of studies that have taken the first of these approaches have looked at a wide range of variables, but one of the few variables that is almost never omitted is investment, either as a flow or a stock (Levine and Renelt, 1992). In a study that employed various permutations to combine the variables used in all the different models (Sala-i-Martín, 1997), the author concludes that investment in equipment is the variable that is the most closely correlated with gross domestic product (GDP). More recently, Qi (2007) -as had Temple and Voth (1998) before her-has found that the link between growth and long-term capital formation is stronger in developing economies. In fact, no macroeconomist who has studied this subject has questioned the existence of a close, statistically robust relationship between capital formation and GDP. The issue on which they are not in agreement is the underlying causality; in other words, the role that physical capital formation plays in driving growth (Bosworth and Collins, 2003). This debate cannot, in all likelihood, be resolved until a broader spatio-temporal database can be constructed - one that incorporates very long-term series on investment in developing countries such as the Latin American nations.

A review of the studies done using a growth accounting approach leads to the same conclusion even more clearly. Studies on industrialized economies show that total factor productivity has been the main driver

\footnotetext{
$\square$ Funding for this study has been provided by the Ministry of Science and Innovation of Spain (Project No. ECO2010-15882). Assistance was provided by Marc Badia, Cristián Ducoing and César Yáñez in locating and reproducing statistics. Sandra Kuntz was kind enough to provide a digital copy of statistics for Mexico which were otherwise unavailable. José Jofré, Frank Notten and Carolina Román helped to build the databases. The author is partially responsible for the data compiled and bears sole responsibility for the way in which they have been processed and for any errors that may be found in these series. The suggestions made by an anonymous CEPAL Review referee were also extremely useful.
}

of growth throughout the twentieth century (Kendrik, 1993). Nonetheless, in all regions of the world other than the geographical area covered by the Organisation for Economic Cooperation and Development (OECD), physical capital formation has played a central role in driving growth, even during the second half of the twentieth century (Bosworth and Collins, 2003). The experiences of countries in Africa (Abu-Qarn and Abu-Bader, 2007) and Asia, both in relation to the "tigers" of South-East Asia and the two Asian giants (China and India), ${ }^{1}$ are informative. There are thus sound reasons for positing that physical capital formation has been one of the main sources of economic growth in Latin America during the past 150 years. The few growth-accounting studies on the subject for the second half of the twentieth century point in this direction. According to Elías (1992), physical capital formation was the most important determinant of growth in the region's major economies between 1940 and 1985. Hofman (2000), who used a much more sophisticated methodology, also found that capital was the most influential factor of production, although he calculated its contribution as being much smaller. In a study that, unlike any of its predecessors, took in all of the Latin American countries except Cuba for the period from 1960 to 2000, Loayza, Fajnzylber and Calderón (2005) found that capital and labour were more or less on a par in terms of their contribution to growth, whereas multifactor productivity did very little to spur growth.

The aim of this study is to provide the academic community with an extensive body of fresh empirical evidence on Latin American countries' investment flows so that scholars looking at long-term growth trends in these economies will have very long-term data series on this fundamental explanatory factor. As is well known, thanks to the series compiled and reworked by Maddison (2007), we still lack estimated GDP series for the vast majority of Latin American countries for the second half of the nineteenth century and even for the early twentieth century in some cases. As a result, the series on capital formation presented here do not shed

\footnotetext{
1 Regarding the South-East Asian economies, see Krugman (1994), Kim and Landau (1994), Young (1994 and 1995), Collins and Bosworth (1996) and Fukuda and Toya (1998). For China and India, see Bosworth and Collins (2008).
} 
light on the links between capital formation and GDP, but rather on a much simpler and more basic question: the approximate trends in GDP in Latin American economies during the years when the capability of measuring them was not yet in place.

This article is structured very simply. Section II describes the method used to estimate gross fixed capital formation (GFCF) for the "pre-statistics era" (the years before official national accounts were kept). Section III covers the long-term trends in GFCF for 1856-2008. Section IV outlines medium- and short-term movements and then offers a brief concluding review. The study closes with a table showing the series that have been compiled for use by researchers in this field.

\section{II}

\section{GFCF estimates for the Latin American countries, 1856-1950}

GFCF estimates are usually calculated in the course of the preparation of national accounts, i.e., on the basis of GDP computations. The vast majority of Latin American countries began to keep official national accounts around 1950, and they did so by following the conceptual and methodological guidelines set out by the United Nations. The support provided by the United Nations' regional agency, the Economic Commission for Latin America and the Caribbean (ECLAC), proved to be a crucial factor in the success of this decentralized, collective effort. Thanks to the ongoing technical assistance and advisory services made available by ECLAC, together with its work in compiling and standardizing the data, the region now has a complete, comparable database on the main supply-side and demand-side components of GDP and on total GDP for all the countries of the region from 1950 onward. ${ }^{2}$ A number of authors have used these statistics to analyse the way in which capital formation and capital stocks influenced the Latin American economies' growth during the second half of the twentieth century.

The picture is a very different one for the years before 1950. Apart from the individual historical series prepared for some economies of the region, the only fairly broad-coverage homogeneous reconstruction of GFCF series is the one developed by André Hofman

\footnotetext{
2 Historical series on aggregates prepared using a standardized methodology (United Nations System of National Accounts 1993 (SNA,1993)) are contained in the database that can be accessed online through ECLAC Cuadernos estadísticos No. 37 (http://www.eclac.cl/ deype/cuaderno37/esp/index.htm). The data for Cuba are limited, and the full annual series therefore usually cover 19 Latin American countries and 13 Caribbean ones. The statistics for the Caribbean nations generally date back only as far as 1970, however. There are some gaps in the series on both Latin American nations and Caribbean countries in the case of the less developed economies. For a discussion of the gaps in capital formation series, see Tafunell (2011).
}

(2000) for 1900 and 1994 for Argentina, Brazil, Chile, Colombia, Mexico and Venezuela. The only precedent for an effort of this type was the preliminary evaluations undertaken by, once again, ECLAC in 1951. No study of this sort had been done on the other 14 Latin American countries, however, and, as a result, trends in capital formation for the region as a whole prior to 1950 are simply unknown.

The main objective of this study is simply to determine the annual levels of fixed capital formation in all the countries of the region during a period of time preceding the introduction of official national accounts. How long should this period be? Ideally, the data should go back as far as the early nineteenth century, when these countries were in the process of becoming independent. The early statistical evidence is of such poor quality, however, that the starting point for the series has to be moved up to midway through that century: 1856, to be exact (Tafunell, 2011). The ongoing civil strife and outright chaos experienced by many of these countries up to around that time (or even later) attests to just how difficult it would be to quantify investment levels on any consistent basis during the decades following these countries' political emancipation. ${ }^{3}$ After calculating the GFCF up to 1950 , the series were merged with the official series compiled by ECLAC. ${ }^{4}$ This should by no means be interpreted as implying that the two series are of comparable quality. They have been merged simply in

\footnotetext{
3 The overview provided by Dye (2006) is helpful in gaining an understanding of the difficulties involved in establish a stable institutional order. For an opposing interepretation that is highly critical of the conventional wisdom on this subject, see Deas (2010).

4 This study focuses solely on the series prepared by the author (i.e., the series for 1856-1950), since the series for years since 1950 are well-known and widely available (see footnote 2 ).
} 
order to obtain a very long-term picture of GFCF trends. This is a legitimate exercise, in the author's view, so long as the results of the quantification are sufficiently reliable.

This statistical reconstruction provides a way of obtaining an overview of the investment activity of all the countries of Latin America, and it has proven to be an almost entirely successful approach. As shown in the tables presented here, measurements of GFCF have been obtained for 17 countries. The only ones that have been omitted are Guatemala, Panama and Paraguay. ${ }^{5}$ Since these three small countries account for no more than a tiny fraction of the region's total GFCF, the series presented here for 17 Latin American countries can be viewed as being representative of Latin America as a whole. ${ }^{6}$

GFCF is an economic aggregate that encompasses capital goods of various sorts which are acquired because they serve as inputs for production process, because of the length of their useful life and, above all, because they help to boost productivity in the economy as a whole thanks to their embedded technologies. In calculating the amount of capital stock that they represent, they are usually divided into four categories: machinery and related equipment, transport equipment, residential construction and non-residential construction. Hofman (2000) used this classification for his study on this subject in six of the larger Latin American economies. Unfortunately, it has not been possible -and may never be possible- to apply his methodology to the other economies of the region, especially for the years preceding the twentieth century. The quantifications that I have prepared have yielded investment series for three categories of goods: machinery and related equipment; transport equipment; and construction. Any attempt to break down this last category into residential and non-residential construction is doomed to failure because the types of indicators or information that would be needed in order to differentiate between the two are simply not available. ${ }^{7}$ Moreover,

\footnotetext{
5 Panama is not covered because the foreign trade statistics compiled by the more industrialized countries, which were the main source for the estimates up to 1929 , attribute merchandise trade flows to that country that were actually directed towards other countries owing to Panama's unique position, thanks to the Panama Canal, as a transit country. The series for Guatemala and Paraguay could not be calculated for 1930-1950 because the data were exceedingly difficult to obtain and/or process.

6 My calculations (based on official statistics published by ECLAC) indicate that the aggregate level of investment for these three countries in 1950 amounted to just $1.3 \%$ of the total for Latin America (20 countries). 7 An arbitrary estimate of investment in residential construction might be derived from the growth patterns of the urban population. This would be a very tenuous approximation, however, since many countries did not carry out population censuses for many years, and very little is known about their urban population trends.
}

the built-in limitations of the official national accounts database maintained by ECLAC are such that the disaggregation of GFCF can be carried only so far. The annual series available in the ECLAC database include just two aggregates: machinery and other equipment, and construction. As a result, the definitive series presented in this article (see the table in the annex) refer only to these two fundamental categories of capital formation.

How have I gone about calculating the levels of these two types of investment? A detailed description of the sources and methods used is provided in Tafunell (2011). A much briefer outline will be provided here owing to space constraints. Official foreign trade statistics are the main -virtually only- source used for this quantification exercise, since the economies of the region presumably purchased their stock of capital goods from more industrialized economies. For the years from 1856 to 1929, trade statistics for Germany, the United States and the United Kingdom have been used; for the period from 1929 to 1950 , the calculations are based on official trade statistics for the Latin American countries themselves. The procedure used to arrive at these estimates is based on the compilation of annual series, using indices for investment in equipment and in construction between 1856 and 1950. The series have been converted into dollars at 1950 prices using the level of investment for that year, in current dollars, as a unit of account (numéraire), as shown in the ECLAC database. The investment indices that I have ended up with are the result of the chain-linking of separate indices for 1856-1890, 1890-1929 and 1929-1950. The investment series for construction are composed of quantum indices based on imports or the apparent consumption of basic inputs (iron and steel for construction plus -from 1900 on- cement). I also ran a sensitivity test for 19251950, comparing the volume (tons) series and the value (constant prices) series for metal inputs in order to verify that using one or the other does not affect the outcome in statistical terms. The series for investment in machinery and other equipment is based on the value of imported goods at 1913 prices for $1856-1929$ and at 1950 prices for 1929-1950. ${ }^{8}$ For Argentina, Brazil and Mexico, I took domestically produced equipment into account and, for those countries plus Chile, Colombia and Cuba, I took

\footnotetext{
8 For the years from 1856 to 1929 , I first computed aggregate investment figures in pounds sterling, German marks and United States dollars at current prices and then converted them into a common currency (pounds). I then deflated the resulting aggregate series using a price index for which the base year of 1913 equals 100. For 1929-1950, I also computed series at current and constant prices, with the latter being derived through the application of implicit unit values for 1950 to the quantity data.
} 
domestically produced iron for use in construction into account as well, since, unlike the situation in the other countries of Latin America, national producers were meeting an appreciable share of demand from the 1930s on. ${ }^{9}$ One point that remains open for discussion, which could lead to a revision of the calculations, is whether or not investment in equipment in Chile, Cuba and Uruguay, and perhaps in some other countries such as Colombia and Peru, should also include domestic output, since it is quite likely that national producers had ceased to be of negligible importance by 1929 or even a few years before then. ${ }^{10}$ The estimates for these countries may also have a slight downward bias because they do not incorporate the output of the railroad companies' machine shops. ${ }^{11}$

\footnotetext{
9 For a more detailed discussion, see Tafunell (2011).

10 In his recently submitted doctoral thesis, Ducoing (2012, pp. 69-70) states that, before the Great Depression, Chilean producers accounted for no more than $3 \%$ of that country's total available supply of equipment even in their best years. During the Second World War, when it became more and more difficult to import equipment, national producers' share of the market climbed to $16 \%$, but shrank again to less than $7 \%$ during the first decade of the post-war period.

11 The studies conducted by Guajardo (1996 and 1998) provide an informative view of the role of railroad machine shops in Chile and
}

The main methodological caveat in terms of the estimates given here has to do with a different aspect, however: investment in construction. Since my measurements are based solely on the apparent consumption of "modern" inputs, such as iron, steel and cement, they are clearly not very representative of activity in housing construction until well into the twentieth century and are actually not sufficiently representative of non-residential construction in the second half of the nineteenth century either. Given the widespread use of traditional materials during those years (stone, wood and clay), my figures on investment in construction surely, at the very least, overstate its long-term growth. ${ }^{12}$
Mexico. They indicate that, even in those countries, where it is thought that they became a force to be reckoned with, they actually accounted for no more than a small share of production.

12 This points up what is quite likely an insurmoutable constraint, since statistics on the production of traditional construction materials are simply not available for this time period. It must be remembered that the large-scale use of iron and steel in infrastructure works came hand-in-hand with the laying of the railroads. For a discussion of the spread of the use of cement, see Tafunell (2007).

\section{III}

\section{The long-term growth of GFCF}

The first aspect of the results of this quantification exercise that is of interest is the long-term growth rate of aggregate investment and the way in which it has varied. GFCF in Latin America, according to my calculations, soared by a factor of 95 between 1856 and 1950, which equates to a cumulative annual growth rate of $5.0 \%$. Interestingly enough, this growth rate exceeds, although not by a large margin, the rate registered for the years following 1950 , since between 1950 and 2008 it rose at an annual rate of $4.4 \%$. The progress made in terms of capitalization during the first stage of the globalization process (up to 1913) outpaced the advances achieved during the "golden age" of State-led industrialization and during the second stage of the globalization process in recent decades (see tables 1 and 2). This clearly has to do with the "Gerschenkron effect", since the growth potential for investment in the nineteenth century was extraordinary given the extremely low levels it had reached around 1850.
Focusing on the period of 1856-1950 (since much less is known about this period than the one that followed), tables 1 and 2 show the average annual growth rates for GFCF in absolute and per-capita terms for the periods associated with the different growth phases that can be identified according to the literature. These figures show that the years 1873 and 1890 marked the turning points at which sharp, sustained surges in investment triggered serious financial crises (Marichal, 1989). The years 1913 and 1929 are so well known to have been turning points in the business cycle that it is unnecessary to dwell on this point here. The graph of the aggregate investment series for Latin America (see figure 1) leaves little doubt as to the appropriateness of the time-based categories shown in the tables. Clearly, figure 1 depicts major short-term movements (movements encompassing a decade or less) which we will look at again later on (see the following section). 
TABLE 1

Cumulative average annual GFCF growth rate

(Percentages)

\begin{tabular}{|c|c|c|c|c|c|c|c|c|c|c|c|c|c|c|c|c|c|c|c|}
\hline Period & 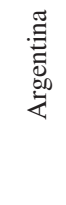 & 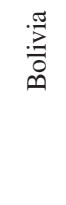 & 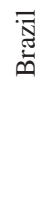 & $\stackrel{0}{\frac{\partial}{\Xi}}$ & $\begin{array}{l}\frac{\pi}{0} \\
\frac{0}{0} \\
0\end{array}$ & 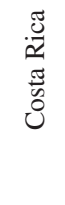 & $\stackrel{\widetilde{Z}}{\Xi}$ & $\begin{array}{c}\grave{0} \\
\stackrel{0}{0} \\
\tilde{J} \\
\text { II }\end{array}$ & 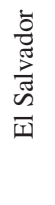 & 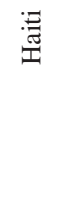 & 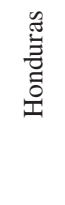 & 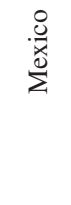 & 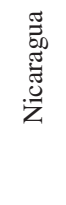 & ᄅ & 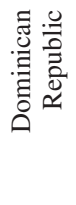 & 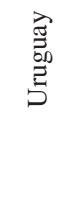 & $\begin{array}{l}\frac{\pi}{0} \\
\frac{\pi}{0} \\
0 \\
0\end{array}$ & 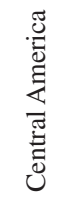 & 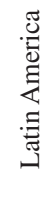 \\
\hline $1856-1$ & & $\ldots$ & 3.8 & 4.0 & 6.2 & $\ldots$ & $4.5^{\mathrm{a}}$ & & ... & 0.1 & $\ldots$ & & $\ldots$ & & $5.7^{\mathrm{a}}$ & $4.2^{\mathrm{a}}$ & & & 2.6 \\
\hline & & $\ldots$ & & 5.8 & & $\ldots$ & $\ldots$ & $\ldots$ & $\ldots$ & $\ldots$ & $\ldots$ & & $\ldots$ & & $\ldots$ & $\ldots$ & & 7.0 & 4.1 \\
\hline $1913-1950$ & & 0.5 & 1.8 & 1.3 & & 2.5 & 1.3 & 4.7 & 4.1 & 2.7 & 4.8 & & 3.0 & & 3.3 & 0.9 & & $\cdots$ & 2.7 \\
\hline $1856-1873$ & & $\ldots$ & 4.5 & 7.6 & 12.9 & $\ldots$ & $\ldots$ & $\ldots$ & $\ldots$ & $\ldots$ & $\ldots$ & 8.1 & $\ldots$ & 12.9 & $\ldots$ & $\ldots$ & 9.4 & 6.9 & 7.1 \\
\hline $1873-1890$ & 16.9 & $\ldots$ & 4.6 & 9.8 & -0.5 & $\ldots$ & 6.0 & 6.1 & $\ldots$ & 5.9 & $\ldots$ & 18.7 & $\ldots$ & -3.6 & 14.0 & 8.4 & 7.1 & 13.2 & 8.7 \\
\hline $1890-1913$ & 1 & 26.7 & 6.0 & 1.5 & & 7.2 & 7.7 & -0.4 & 2.1 & 8.0 & 15.5 & -0.3 & -0.9 & 5.5 & 3.2 & 5.8 & 0.7 & 2.7 & 4.1 \\
\hline 1913-1929 & 1. & 2.7 & 1.0 & 4.7 & 11.9 & 6.2 & 0.4 & 8.5 & 6.8 & 1.1 & 2.7 & 5.8 & 6.6 & 7.6 & 1.9 & 6.0 & 14.7 & 5.5 & 7.3 \\
\hline $1929-1950$ & 1.8 & -1.2 & 2.4 & -1.2 & 2.4 & -0.3 & 2.0 & 2.0 & 2.0 & 4.0 & 6.4 & 5.8 & 0.3 & 4.4 & 4.4 & -2.9 & 5.6 & $\ldots$ & 3.2 \\
\hline $1950-1980$ & 4.7 & 4.9 & 7.4 & 3.3 & 5.3 & 8.3 & $\ldots$ & 8.0 & $\ldots$ & 5.9 & 8.2 & & 6.5 & 5.9 & 8.5 & 2.4 & 5.1 & $\ldots$ & 6.6 \\
\hline $1980-2008$ & 1.9 & 3.4 & 1.1 & 7.0 & 3.9 & 4.6 & $\cdots$ & 1.4 & $\ldots$ & 2.8 & 4.3 & 2.6 & 2.9 & 3.3 & 5.5 & 0.1 & 1.3 & $\ldots$ & 2.2 \\
\hline
\end{tabular}

Source: Prepared by the author on the basis of the annex table and http://www.cepal.org/deype/cuaderno37/esp/index.htm.

a $1870-1950$.

b $1865-1950$.

GFCF: Gross fixed capital formation.

TABLE 2

Cumulative average annual rate of GFCF per capita

(Percentages)

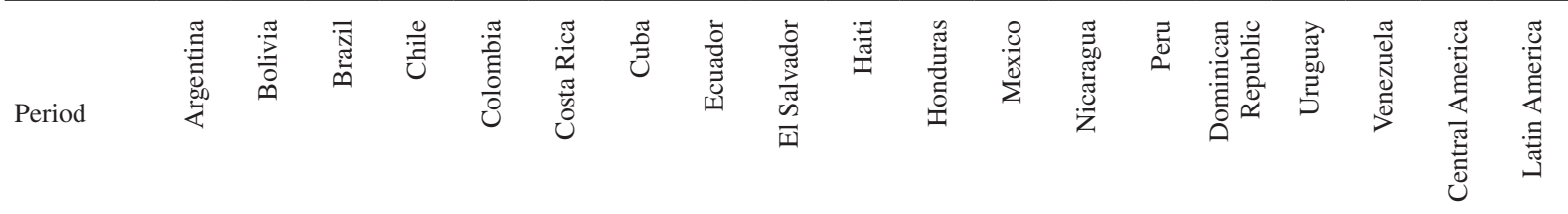

\begin{tabular}{rrrrrrrrrrrrrrrrrrrrrr}
\hline $1856-1950$ & 2.8 & $\ldots$ & 1.7 & 2.5 & 4.4 & $\ldots$ & $2.6^{\mathrm{a}}$ & $4.0^{\mathrm{b}}$ & $\ldots$ & $3.8^{\mathrm{a}}$ & $\ldots$ & 5.5 & $\ldots$ & 3.8 & $2.7^{\mathrm{a}}$ & $1.8^{\mathrm{a}}$ & 5.4 & $\ldots$ & 3.2 \\
$1856-1913$ & 4.9 & $\ldots$ & 3.2 & 4.3 & 4.6 & $\ldots$ & $\ldots$ & $\ldots$ & $\ldots$ & $\ldots$ & $\ldots$ & 6.5 & $\ldots$ & 3.5 & $\ldots$ & $\ldots$ & 3.8 & 5.6 & 4.8 \\
$1913-1950$ & -0.4 & -0.6 & -0.4 & -0.3 & 4.2 & 0.2 & -1.0 & 2.8 & 2.2 & 1.4 & 2.6 & 4.0 & 1.2 & 4.2 & 0.2 & -0.8 & 7.8 & $\ldots$ & 0.7 \\
$1856-1873$ & 7.1 & $\ldots$ & 2.9 & 6.0 & 11.5 & $\ldots$ & $\ldots$ & $\ldots$ & $\ldots$ & $\ldots$ & $\ldots$ & 7.1 & $\ldots$ & 11.6 & $\ldots$ & $\ldots$ & 8.1 & 5.6 & 5.9 \\
$1873-1890$ & 13.3 & $\ldots$ & 2.7 & 8.3 & -1.7 & $\ldots$ & 5.0 & 5.0 & $\ldots$ & 4.9 & $\ldots$ & 17.3 & $\ldots$ & -4.3 & 11.2 & 4.7 & 5.5 & 11.6 & 9.1 \\
$1890-1913$ & -2.3 & 25.9 & 3.7 & 0.3 & 4.3 & 4.9 & 5.8 & -1.7 & 1.0 & 6.7 & 12.4 & -1.3 & -2.7 & 3.8 & 0.4 & 3.3 & -0.4 & 1.4 & 0.9 \\
$1913-1929$ & -0.9 & 1.2 & -1.1 & 3.3 & 9.1 & 4.4 & -2.2 & 7.6 & 4.6 & -0.4 & 0.5 & 5.0 & 5.6 & 6.1 & -1.1 & 3.7 & 13.8 & 3.9 & 1.6 \\
$1929-1950$ & -0.1 & -1.9 & 0.0 & -2.9 & 0.5 & -3.0 & -0.1 & -0.7 & 0.5 & 2.7 & 4.3 & 3.2 & -2.0 & 2.7 & 1.2 & -4.1 & 3.5 & $\ldots$ & 0.1 \\
$1950-1980$ & 3.0 & 2.6 & 4.5 & 1.3 & 2.4 & 5.1 & $\ldots$ & 5.0 & $\ldots$ & 3.9 & 5.0 & 5.1 & 3.2 & 3.1 & 5.3 & 1.5 & 1.3 & $\ldots$ & 3.6 \\
$1980-2008$ & 0.6 & 1.1 & -0.6 & 5.4 & 2.1 & 2.2 & $\ldots$ & -0.6 & $\ldots$ & 0.9 & 1.7 & 1.0 & 0.9 & 1.5 & 3.6 & -0.4 & -0.9 & $\ldots$ & 0.4 \\
\hline
\end{tabular}

Source: prepared by the author on the basis of the annex table and http://www.cepal.org/deype/cuaderno37/esp/index.htm ; and, for population: C. Yánez and others, "La población de los países latinoamericanos desde el siglo XIX hasta 2008. Ensayo de historia cuantitativa", Documento de trabajo, No. 1202, Asociación Española de Historia Económica, 2012.

a $1870-1950$.

b $1865-1950$.

GFCF: gross fixed capital formation. 
FIGURE 1

GFCF in Latin America, in constant dollars at 1950 prices

(Index: $1950=100$ )

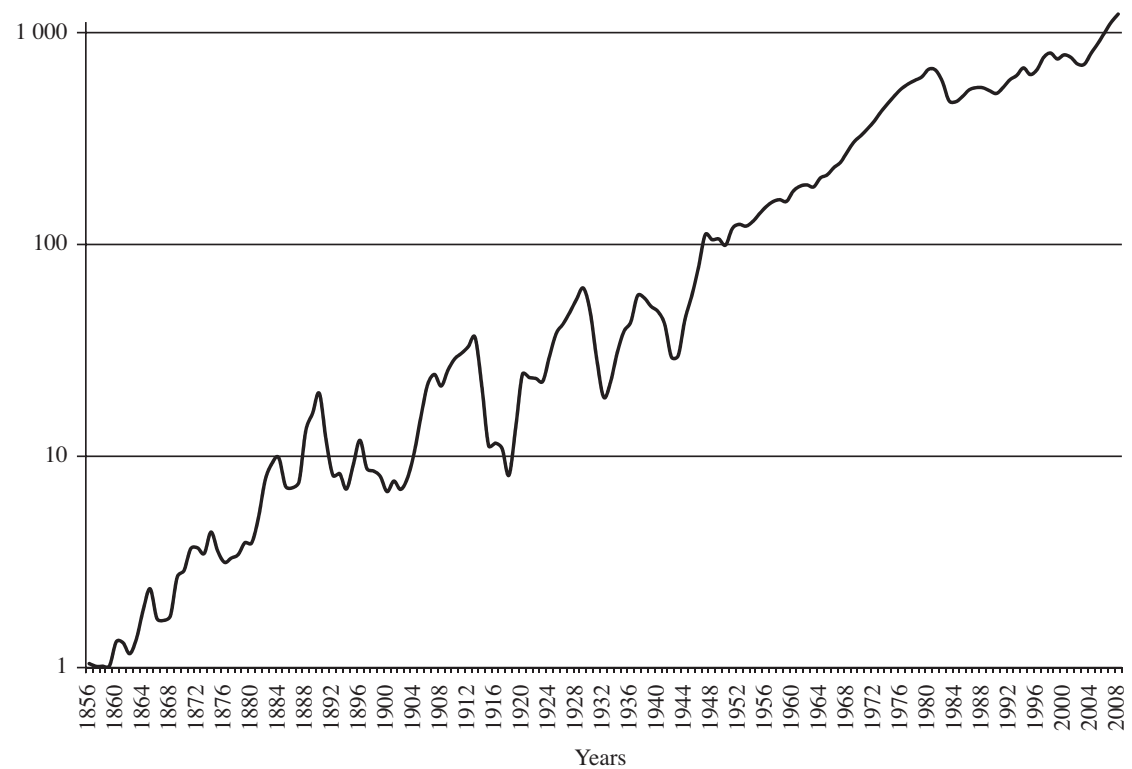

Source: prepared by the authors on the basis of the annex table.

GFCF: gross fixed capital formation.

Focusing on the way in which the long-term capitalization process unfolded in Latin America as a whole, figure 1 and tables 1 and 2 shed light on two particularly interesting factors. One is that the peak in investment activity did not occur during the second half of the twentieth century, as is usually thought, but rather in the second half of the nineteenth century. This is especially evident when investment activity is measured in per-capita terms. The growth rate for GFCF from 1856 to 1890 was not equalled at any point in the twentieth century. The second outstanding feature of aggregate investment trends is the marked degree of volatility seen in the 100 years leading up to 1950 . Figure 1 shows quite clearly how investment growth cycles and phases have smoothed out since then. In fact, this change in trend is so marked that it may be regarded as signalling the emergence of a different and less unstable investment pattern. ${ }^{13}$

\footnotetext{
13 The fact that this change in investment trends coincides with the point in time when these estimates begin to be based on official figures would seem to be grounds for a strong suspicion that this changover in data sources may be the reason why the series for the years before 1950 reflect a much greater degree of volatility than the post-1950 series do. I have been unable to find any corroborating evidence for that suspicion, however.
}

Turning back to the first point: the data indicate that the slowdown in investment actually began before the outbreak of the First World War. The period between 1890 and 1913 was one of slow growth, as capital formation was depressed for the entire decade following the Baring crisis, which set foreign investors back for years. In the following period (1913-1929), a moderate upswing in growth was cut short by the Great Depression. The period 1929-1950 was the least robust stage in the 150 years covered by this analysis, along with 1980-2008; in fact, it was so sluggish that, in per capita terms, total output was completely flat (see table 2). This evidence strongly refutes the traditional historical narrative, in which investment was said to have jumped with the advent of the import-substitution industrialization model which followed the disruption caused by the Great Depression. ${ }^{14}$ It would seem that the financial squeeze

14 The traditional view is taken up, from a critical perspective, in the essays of Luis Bértola and Jeffrey Williamson, Stephen Haber and Richard Salvucci that have been published in Bulmer-Thomas, Coatsworth and Cortés Conde (2006). The analysis authored by José A. Ocampo (2004) could be said to set out-for now- the canonical position on this issue, according to which the industrialization process gathered a huge amount of momentum in the 1930s and during the Second World War while not radically changing the development pattern of Latin America that had been in place up to the crisis of 1929 . 
occasioned by the interruption of external capital inflows and the decline in the purchasing power of exports played a more important part than government action did in galvanizing investment.

Another noteworthy and rather surprising feature of tables 1 and 2 are the differences between countries over a century of GFCF growth. The rates of capital accumulation do not correlate to relative levels of per capita income in 1950, according to data published by Maddison (2007). Mexico, the Dominican Republic (only in absolute terms) and Colombia exhibit the highest rates of capitalization between 1856 and 1950, yet their per capita GDP was below the average for Latin America in 1950. Also surprising is the fact that Ecuador and Haiti - two very laggard economies - built up capital at the same rate as the region overall. ${ }^{15}$ Something similar may be supposed to have happened in Central America: although the evolution of investment has not been estimated for 1929-1950, in 1856-1929 it gained more ground than in Latin America overall. Conversely, some of the region's more developed economies, such as Chile, capitalized at below-average rates. The trajectories for other countries coincide with what might be expected in relation to their degree of economic development. It comes as no surprise, then, that investment in Argentina progressed further and investment in Brazil less than the regional average. Incidentally, investment patterns over the century provide the best illustration of the way the major investment opportunities offered by the first wave of globalization contrasted with the limited possibilities available once the international economy began to disintegrate.

What explanation can there be for the fact that national GFCF growth rates in 1856-1950 are so unrelated, in many cases, to relative per capita GDP around 1950 ? The unexpected figures in tables 1 and 2 seem to cast an ominous doubt on the consistency of the quantification, regardless that previous findings (Tafunell, 2007, 2009a and 2009b) confirm its reliability. The key to the paradox lies, basically, in the starting levels of investment. These were very uneven in the mid-nineteenth century, as we will see below. But first, a look is warranted at how the two basic categories of investment (equipment and construction) evolved. These series are represented in figure 2. Tables 3 and 4 contain the figures for the average annual rates of variation for both categories in the periods under review.

\footnotetext{
15 In these two cases, the growth rates do not refer to the total period because information is lacking for the first few years. But it is unlikely that the results would vary significantly if we had those data.
}

In figure 2 it leaps to the eye that capital formation in machinery and related equipment climbed more vigorously than investment in construction (and more, obviously, than overall investment). This makes sense, since long-term economic growth depends more on the endowment and quality of machinery than on the acquisition and renewal of other capital goods. In Latin America, during the century prior to 1950, the difference between the two annual growth rates was quite considerable: $6.3 \%$, compared with 4.6. ${ }^{16}$ Interestingly, the difference between the two rates was greatest in the period 1856-1913 (8.5\% and 5.9\%, respectively), then it narrowed sharply in 1913-1950 (3.1\% and $2.6 \%$, respectively). What is more, between 1929 and 1950, the relative positions shifted: capital formation in equipment rose very little, whereas investment in construction rose in keeping with its moderate growth since 1890. Figure 2 shows very clearly that capital formation grew faster in equipment than in construction until 1890. Since then, the two series have followed a very similar long-term trajectory. All this backs up the idea mentioned earlier that the capitalization process in the second half of the nineteenth century was materially different to the process in the first half of the twentieth century.

This is, undoubtedly, the most important lesson to be drawn from the comparison between tables 3 and 4. The varied investment profiles of the growth phases between 1856 and 1950 are also interesting to examine. In the upsurge of 1856 to 1873 , equipment stock was accumulated at an extraordinarily high — and never repeated - annual rate of $12.2 \%$, almost double the rate for investment in construction. In the following phase (1873-1890) the frenetic pace of railway laying drove growth in construction investment ahead of still-dynamic investment in machinery. The financial crisis of 1890 dealt a harsh blow to the transport sector, with lasting effects, while the equipment endowment rose from then until 1929 at a respectable annual rate of almost $6 \%$. From a general perspective, the data in table 4 are notably similar to those in table 1, owing to the heavy weight of construction investment in GFCF. ${ }^{17}$

\footnotetext{
16 For example, in Spain the rates of increase over this century-long period were, respectively, $3.3 \%$ and $2.5 \%$, with an aggregate investment growth rate of $2.6 \%$ per year, according to series prepared by Prados de la Escosura (2003).

17 It will be recalled that the index numbers series for the two categories of GFCF have been transformed by applying the magnitude of GFCF in 1950, at that year's prices. At that date, investment in construction represented $63.8 \%$ of overall investment in Latin America (17 countries). It is worth adding that the differences between countries in this respect are not very significant, with a standard deviation of 8.8 .
} 
FIGURE 2

GFCF in Latin America, in constant dollars at 1950 prices

(Index: 1929=100)

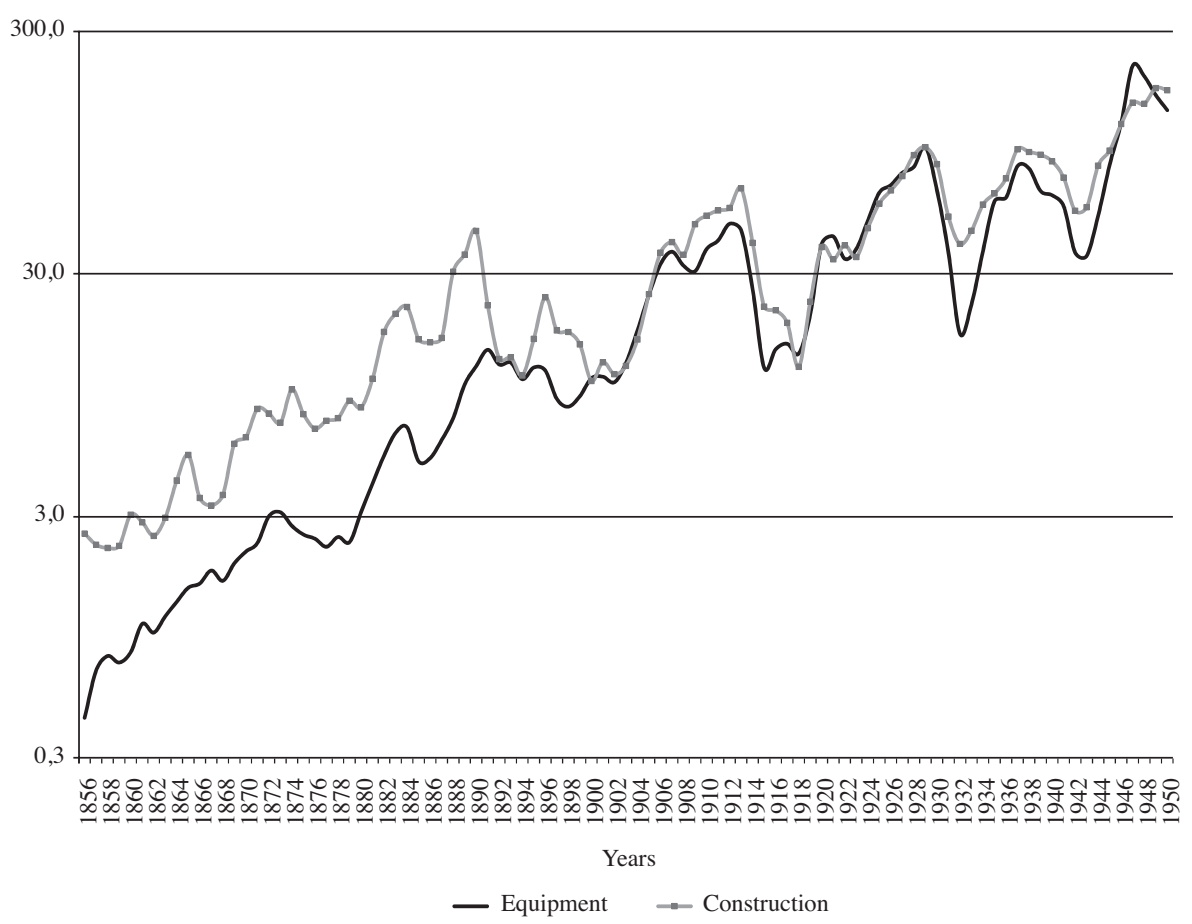

Source: prepared by the author on the basis of the annex table.

GFCF: gross fixed capital formation.

TABLE 3

Cumulative average annual growth rate of gross investment in equipment (Percentages)

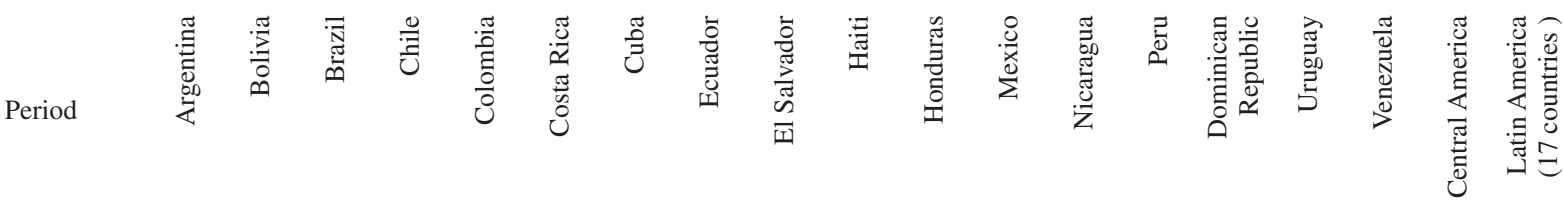

\begin{tabular}{rrrrrrrrrrrrrrrrrrrrrr}
\hline $1856-1950$ & 8.4 & $\ldots$ & 5.8 & 5.3 & 5.4 & $\ldots$ & $4.5^{\mathrm{a}}$ & $7.3^{\mathrm{b}}$ & $\ldots$ & $5.0^{\mathrm{a}}$ & $\ldots$ & 7.8 & $\ldots$ & 6.6 & $4.7^{\mathrm{a}}$ & $4.6^{\mathrm{a}}$ & 7.7 & $\ldots$ & 6.3 \\
$1856-1913$ & 11.7 & $\ldots$ & 8.9 & 7.9 & 5.9 & $\ldots$ & $\ldots$ & $\ldots$ & $\ldots$ & $\ldots$ & $\ldots$ & 9.1 & $\ldots$ & 6.7 & $\ldots$ & $\ldots$ & 6.0 & 7.7 & 8.5 \\
$1913-1950$ & 3.4 & -0.5 & 1.1 & 1.4 & 4.6 & 1.7 & 2.8 & 4.6 & 4.2 & 4.9 & 7.2 & 5.8 & 1.8 & 6.5 & 1.4 & 1.6 & 10.3 & $\ldots$ & 3.1 \\
$1856-1873$ & 13.2 & $\ldots$ & 12.0 & 11.0 & 13.4 & $\ldots$ & $\ldots$ & $\ldots$ & $\ldots$ & $\ldots$ & $\ldots$ & 14.1 & $\ldots$ & 19.0 & $\ldots$ & $\ldots$ & 3.5 & 4.1 & 12.2 \\
$1873-1890$ & 19.5 & $\ldots$ & 7.8 & 9.5 & -1.1 & $\ldots$ & 6.2 & 22.3 & $\ldots$ & 9.1 & $\ldots$ & 11.1 & $\ldots$ & -5.0 & 20.4 & 9.5 & 10.1 & 15.9 & 8.5 \\
$1890-1913$ & 5.2 & 33.4 & 7.5 & 4.6 & 6.0 & 5.2 & 4.5 & 7.9 & 5.6 & 3.2 & 8.3 & 4.0 & 1.9 & 7.3 & 6.0 & 3.1 & 4.8 & 4.6 & 5.8 \\
$1913-1929$ & 6.1 & 3.8 & 1.8 & 6.4 & 12.6 & 6.1 & 0.9 & 6.1 & 4.7 & 7.5 & 5.8 & 6.4 & 5.4 & 4.8 & 0.9 & 5.6 & 12.8 & 5.8 & 5.1 \\
$1929-1950$ & 1.5 & -3.6 & 0.6 & -2.2 & -1.1 & -1.5 & 4.3 & 3.4 & 3.8 & 3.0 & 8.3 & 5.3 & -0.9 & 7.7 & 7.8 & -1.3 & 8.4 & $\ldots$ & 1.7 \\
\hline
\end{tabular}

Source: prepared by the author on the basis of the annex table.

a $1870-1950$.

b $1865-1950$. 


\begin{tabular}{|c|c|c|c|c|c|c|c|c|c|c|c|c|c|c|c|c|c|c|c|}
\hline Period & 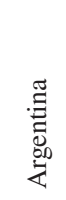 & 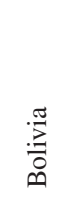 & $\begin{array}{l}\overline{\mathbb{N}} \\
\stackrel{\mathscr{D}}{n}\end{array}$ & 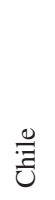 & $\begin{array}{l}\frac{\pi}{0} \\
\frac{0}{0} \\
0\end{array}$ & 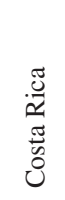 & $\stackrel{\widetilde{Z}}{ٍ}$ & $\begin{array}{l}\ddot{0} \\
\tilde{J} \\
\tilde{J} \\
\text { I }\end{array}$ & 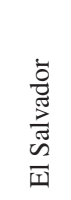 & : & 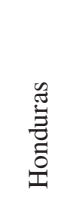 & $\begin{array}{l}\frac{0}{x} \\
\sum_{\Sigma}^{e}\end{array}$ & 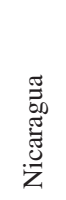 & $\begin{array}{l}\vec{D}_{0} \\
0\end{array}$ & 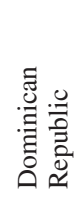 & 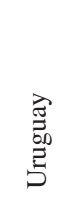 & $\begin{array}{l}\frac{\pi}{0} \\
\stackrel{0}{0} \\
\stackrel{0}{0} \\
>\end{array}$ & 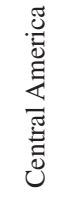 & 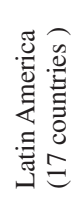 \\
\hline $1856-1950$ & 5.3 & $\ldots$ & 3.4 & 3.5 & 6.8 & $\ldots$ & $4.5^{\mathrm{a}}$ & $5.1^{\mathrm{b}}$ & $\ldots$ & $5.2^{\mathrm{a}}$ & $\ldots$ & 6.4 & $\ldots$ & 4.7 & $6.4^{\mathrm{a}}$ & 5.7 & 6.5 & . & 4.6 \\
\hline $1856-1913$ & 8.0 & $\ldots$ & 4.1 & 4.9 & 6.1 & $\ldots$ & $\ldots$ & $\ldots$ & $\ldots$ & $\ldots$ & $\ldots$ & 6.8 & $\ldots$ & 4.3 & $\ldots$ & 9.1 & 4.9 & 7.0 & 5.9 \\
\hline $1913-1950$ & 1.3 & 1.2 & 2.3 & 1.2 & 7.9 & 3.3 & 0.0 & 4.9 & 4.0 & 2.3 & 4.2 & 5.8 & 5.5 & 5.4 & 4.6 & 0.6 & 9.0 & $\ldots$ & 2.6 \\
\hline $1856-1873$ & 9.8 & $\ldots$ & 3.5 & 6.9 & 12.1 & $\ldots$ & $\ldots$ & $\ldots$ & $\ldots$ & $\ldots$ & $\ldots$ & 4.5 & $\ldots$ & 11.5 & $\ldots$ & 13.2 & 10.2 & 7.7 & 6.4 \\
\hline $1873-1890$ & 16.8 & $\ldots$ & 3.4 & 9.9 & 0.6 & $\ldots$ & 5.6 & 5.6 & $\ldots$ & 5.0 & $\ldots$ & 23.2 & $\ldots$ & -3.1 & 12.5 & 7.8 & 6.8 & 12.5 & 11.3 \\
\hline $1890-1913$ & 0.8 & 23.6 & 5.0 & 0.0 & 6.0 & 12.9 & 11.3 & -3.0 & 0.8 & 9.2 & 18.8 & -2.2 & -5.5 & 4.8 & 1.2 & 7.1 & -0.2 & 2.5 & 1.8 \\
\hline 1913-1929 & 5.1 & 34.3 & 0.8 & 2.2 & 7.5 & 11.3 & 16.8 & 0.6 & -1.5 & 4.1 & 29.0 & -2.9 & -3.1 & -2.6 & 1.4 & 6.1 & -0.6 & 3.1 & 2.5 \\
\hline $1929-1950$ & 1.9 & 1.3 & 3.9 & 0.0 & 5.7 & 0.9 & -0.1 & 0.9 & 1.1 & 4.3 & 5.9 & 6.3 & 2.0 & 2.9 & 6.0 & -3.5 & 4.4 & $\ldots$ & \\
\hline
\end{tabular}

Source: prepared by the author on the basis of the annex table.

a $1870-1950$.

b $1865-1950$.

We now return to the questions that remained unanswered from the reading of tables 1 and 2. A working hypothesis may be formed on the basis of table 5 . The first few rows of data speak of very uneven levels of investment per capita within the region around 1856. These levels were uneven later, too, in fact throughout the period under study. And it may be tempting to say that there have always been huge inequalities in this respectas there are, indeed, in other economic aggregates. In colonial times, especially latterly, levels of production activity, and in all probability investment, are known to have differed greatly in the various territories, although these disparities were not necessarily exactly as shown in the first few rows of table 5. All the evidence available points to early development — around the middle third of the nineteenth century - in a few economies such as Cuba, Argentina, Chile and Uruguay (probably in that order), and to lag and stalled or very weak growth in that period in other economies such as Colombia, Ecuador, Bolivia, Mexico, Peru, Venezuela and the small Central American states, except for Costa Rica. 18

What is really startling in table 5 are the gaping differences in the endowment of new capital per capita by the middle decades of the nineteenth century. Whereas

18 Bértola and Ocampo (2010, p. 19) note that economic inequalities were very great in the period 1820-1870. They find that Argentina and Uruguay were the earliest developers, followed by Chile and Cuba.
Argentina and Chile were investing around US\$ 9 (at 1950 prices) annually per capita, Mexico, the Central American nations, Peru and Colombia were investing $\mathrm{US} \phi 16$, US $\varnothing 45$, US $\varnothing 74$ and US $\phi 89$, respectively. We now turn to the data for the 1870 s, when economic globalization was beginning to inject vigour into the Latin American economies, and for which my data processing spans a larger and more representative group of nations. Taking the leading economy, Argentina, as a reference, we see that the investment effort in the next most prosperous economies (Chile and Uruguay) was around $50 \%$ and $75 \%$ of Argentina's, as shown in table 5, ${ }^{19}$ and $25 \%$ of that figure for Latin America as

\footnotetext{
19 Cuba should also figure in this group, but the Ten Years' War (18681878) depressed investment in the country. With regard to Uruguay, the data in the table and the annex require some clarification. My estimate for investment in construction yields figures too high to be credible until, at least, the final years of the nineteenth century. Fortunately, there is another measurement with which to compare and substitute mine: one prepared by Bértola (1998). This author calculated the gross value added of the construction industry on the basis of data on building permits and public works spending. Comparison of his series and mine shows that the two have a broadly similar profile in terms of cyclical movements, but diverge significantly as to level before 1900 . For want of a better explanation, I assume that my figures grossly overstate the level of investment in Uruguay because much of the material imported through the port of Montevideo was in fact destined for the Argentine market. This is mere conjecture, however, and needs to be verified. Meanwhile, I have adopted the series constructed by Bértola and linked it with mine in 1870 and 1936.
} 
TABLE 5

GFCF per capita in dollars at constant 1950 prices

(Ten-year averages)

\begin{tabular}{|c|c|c|c|c|c|c|c|c|c|c|c|c|c|c|c|c|c|c|c|}
\hline Period & 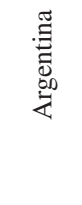 & 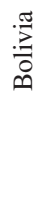 & $\begin{array}{l}\overline{\mathbb{N}} \\
\text { صี }\end{array}$ & $\frac{\mathscr{U}}{\tilde{U}}$ & $\begin{array}{l}\frac{\pi}{0} \\
\frac{0}{0} \\
\frac{0}{0}\end{array}$ & 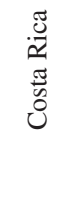 & $\stackrel{\widetilde{0}}{\Xi}$ & 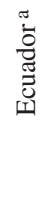 & 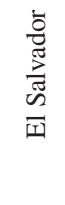 & 苛 & 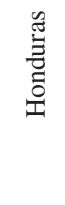 & $\frac{\stackrel{0}{x}}{\sum_{\Sigma}^{0}}$ & 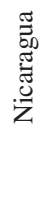 & $\begin{array}{l}\overrightarrow{0} \\
0 \\
0\end{array}$ & 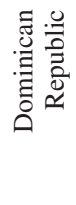 & $\begin{array}{l}\vec{\Xi} \\
\stackrel{\Xi}{0} \\
\Xi \\
\Xi\end{array}$ & $\begin{array}{l}\frac{\pi}{0} \\
\stackrel{N}{0} \\
\stackrel{0}{0}\end{array}$ & 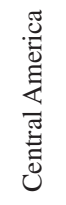 & 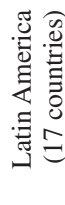 \\
\hline $1856-1859$ & 9.3 & $\ldots$ & 6.1 & 9.3 & 0.9 & $\ldots$ & $\ldots$ & $\ldots$ & $\ldots$ & $\ldots$ & $\ldots$ & 0.2 & $\ldots$ & 0.7 & $\ldots$ & $\ldots$ & 2.0 & 0.5 & 3.0 \\
\hline $1860-1869$ & 22.1 & $\ldots$ & 6.3 & 13.6 & 3.4 & $\ldots$ & $\ldots$ & 0.3 & $\ldots$ & $\ldots$ & $\ldots$ & 0.6 & $\ldots$ & 1.2 & $\ldots$ & ... & 3.1 & 0.6 & 4.9 \\
\hline $1870-1879$ & 35.5 & $\ldots$ & 11.8 & 17.7 & 5.3 & $\ldots$ & 7.6 & 0.9 & $\ldots$ & 0.7 & $\ldots$ & 1.0 & $\ldots$ & 4.4 & 3.6 & 27.0 & 4.1 & 2.1 & 8.8 \\
\hline $1880-1889$ & 120.0 & $\ldots$ & 13.6 & 24.2 & 8.2 & $\ldots$ & 8.8 & 2.6 & $\ldots$ & 0.8 & $\ldots$ & 3.4 & $\ldots$ & 1.1 & 9.0 & 56.8 & 14.4 & 5.3 & 18.1 \\
\hline $1890-1899$ & 82.0 & 0.1 & 16.9 & 34.6 & 5.8 & 20.8 & 19.8 & 3.1 & 5.7 & 2.6 & 0.7 & 6.4 & 4.3 & 1.6 & 10.8 & 35.0 & 10.2 & 9.4 & 17.9 \\
\hline 1900-1909 & 94.6 & 0.9 & 13.9 & 43.1 & 4.6 & 28.4 & 33.1 & 3.2 & 2.2 & 1.3 & 1.2 & 8.8 & 2.5 & 2.8 & 4.0 & 55.4 & 4.5 & 6.2 & 19.7 \\
\hline $1910-1919$ & 90.7 & 1.3 & 18.7 & 50.6 & 9.5 & 25.7 & 56.5 & 3.4 & 4.8 & 3.8 & 5.6 & 6.3 & 4.0 & 3.2 & 13.1 & 91.9 & 10.9 & 8.4 & 24.4 \\
\hline 1920-1929 & 92.6 & 2.5 & 21.9 & 64.5 & 36.9 & 42.6 & 55.2 & 8.7 & 12.2 & 4.0 & 9.9 & 11.7 & 7.4 & 7.4 & 19.4 & 204.4 & 70.2 & 17.3 & 33.9 \\
\hline $1930-1939$ & 96.3 & 2.2 & 17.1 & 49.6 & 27.8 & 53.7 & 14.1 & 6.4 & 7.0 & 2.7 & 8.4 & 12.1 & 4.7 & 6.7 & 7.1 & 167.8 & 100.8 & $\ldots$ & 31.4 \\
\hline $1940-1950$ & 106.4 & 3.0 & 25.4 & 60.3 & 45.5 & 57.3 & 25.4 & 8.4 & 10.4 & 4.7 & 12.8 & 24.2 & 7.5 & 15.3 & 12.5 & 91.8 & 233.2 & $\ldots$ & 42.8 \\
\hline
\end{tabular}

Source: X. Tafunell, “Un siglo de formación de capital en América Latina (1856-1950). Ensayo de cuantificación general”, paper presented at the X International Congress of the Spanish Association of Economic History (Carmona, Spain, 7-9 September), 2011.

a The figure shown for 1860-1869 is the average for 1865-1869.

GFCF: gross fixed capital formation.

a group. The most laggard economies show investment efforts of less than 10\% of the figure for Argentina: $8.1 \%$ for the Dominican Republic; 6\% for the small Central American states; $2.9 \%$ for Mexico; $2.6 \%$ for Ecuador; and $1.8 \%$ for Haiti. Ahead of this group of severely undercapitalized economies was another group, with investment levels that were still very low, comprising Colombia (15.1\% of Argentina's level), Peru (12.7\%) and Venezuela (11.5\%).

What emerges from table 5 , then, is that the economies that were the region's richest at the end of the first globalization period (Argentina, Uruguay, Chile and Cuba) made headway in capital formation very early on. In the middle decades of the nineteenth century, if not before, these countries enjoyed an investment boom as a result of which their per capita investment levels were, fluctuations notwithstanding, several times those of poor economies by the starting point of the series (1856-1859). It follows, then, that great divergence must have occurred within the region in the first half of the nineteenth century. This being so, the more laggard economies, whose levels of capitalization per capita were tiny around 1850 , would naturally tend to capitalize faster than the advanced economies whenever the opportunity arose, as is apparent in table 2 . This, of course, produced a certain amount of convergence within the region, at least in terms of capital formation. In an earlier work (Tafunell, 2009a), I postulated this hypothesis for the period 1914-1930. ${ }^{20}$ Now, the data processing over a much longer period seems to bear out that hypothesis for the century and a half since 1856 . A more careful analysis of the series, beyond this rapid presentation of the qualitative reconstruction performed, would test this hypothesis and its validity for different historical subperiods.

20 Bértola and Ocampo (2010, pp. 19-20 and 26) argue that there was a process of economic convergence in the region from 1910 to 1990. 


\section{IV}

\section{Fluctuations in GFCF: cycles and volatility}

Figure 1 shows a markedly cyclical dynamic. Shortterm movements (of no more than a decade) prevail over long-term growth trends of the aggregate. The cyclical fluctuations over the course of several historical intervals are large enough and sharp enough to eclipse underlying trends.

The cyclical peaks depicted in figure 1 are compiled in table 6 , which shows the cumulative average annual growth rate recorded in each of these cycles - from high to high - and a simple measure of investment volatility, the standard deviation of the year-on-year variation rates.

TABLE 6

GFCF cycles in Latin America

\begin{tabular}{|c|c|c|}
\hline Period & $\begin{array}{l}\text { Average annual } \\
\text { rate of growth } \\
\text { (percentages) }\end{array}$ & $\begin{array}{c}\text { Standard deviation } \\
\text { of year-on-year } \\
\text { variation rates }\end{array}$ \\
\hline $1856-1860$ & 5.9 & 13.7 \\
\hline 1860-1865 & 11.5 & 16.1 \\
\hline $1865-1874$ & 7.9 & 19.2 \\
\hline 1874-1884 & 7.5 & 16.4 \\
\hline $1884-1890$ & 14.6 & 27.7 \\
\hline 1890-1896 & -9.1 & 29.5 \\
\hline 1896-1907 & 6.6 & 22.9 \\
\hline 1907-1913 & 6.7 & 9.8 \\
\hline 1913-1920 & -5.9 & 44.6 \\
\hline 1920-1929 & 11.6 & 23.5 \\
\hline 1929-1937 & -1.1 & 28.4 \\
\hline 1937-1947 & 6.9 & 25.4 \\
\hline 1947-1949 & -2.8 & 21.6 \\
\hline 1949-1952 & 5.4 & 9.6 \\
\hline $1952-1958$ & 4.6 & 3.7 \\
\hline 1958-1962 & 4.1 & 4.6 \\
\hline $1962-1980$ & 7.2 & 3.5 \\
\hline 1980-1987 & -2.8 & 9.0 \\
\hline 1987-1994 & 3.1 & 4.5 \\
\hline 1994-1998 & 4.1 & 7.0 \\
\hline $1998-2000$ & -1.0 & 5.1 \\
\hline 2000-2008 & 5.7 & 7.0 \\
\hline $1856-1950$ & 4.9 & 25.3 \\
\hline $1950-2008$ & 4.4 & 6.8 \\
\hline $1856-2008$ & 4.7 & 20.4 \\
\hline
\end{tabular}

Source: prepared by the author on the basis of the annex table and http://www.cepal.org/deype/cuaderno37/esp/index.htm.

GFCF: gross fixed capital formation.
Leaving aside the well-known events since the Second World War, a first point which merits attention is that there were only three episodes of slippage: 18901896, 1913-1920 and 1929-1937.

In the first of these cycles the fall was very sharp: almost half (43.7\%) measured from high to high. The data show, then, that the Baring crisis had a deeply depressive effect that set it apart from other crises, as several authors have argued (Mitchener and Weidenmier, 2008). The plunge caused by the First World War was not as deep, thanks to the powerful reactivation that ensued in 1919-1920. In the last of the three cycles (1929-1937) the contraction endured during the fateful years of the Great Depression weighed more heavily than the upturn generated by the kick-start of industrialization by import substitution. A final interesting point in this connection is that capitalization slumped more heavily in the two great depressions mentioned than in the "lost decade" of the 1980s.

Turning to cycles dominated by the upswing, the first observations is that these predominate overwhelmingly: high positive average annual rates of variation characterized 9 of the 12 cyclical movements identified. The cycles with the largest overall increases measured from peak to peak were 1884-1890, 1860-1865 and 1920-1929. The first stands out significantly from the others. The other two were similar, but given that the last doubled the first in length, it may be said that the two largest cyclical investment drives in pre-1950 Latin America occurred in the 1880s and the 1920s. This is consistent with the fact that the contractions that ended these booms were the severest in the century between 1856 and 1950, except for the downturn during the First World War. Obviously, the latter was exceptional inasmuch as its cause was wholly exogenous, unlike other investment crises. What is more, all the cycles - except those indicated - were characterized by a relatively high and stable rate of investment growth: between $6 \%$ and $8 \%$ per year. This was, according to the data, the cruising speed at which Latin America managed to capitalize until the Second World War. The region departed from this investment pattern - with either positive or negative variations - only during a few periods of turbulence in extraordinary circumstances. Since the Second World War, the stationary rate of investment has been lower, from $4 \%$ to $5 \%$ per year. The most obvious deviation 
from this cyclical pattern occurred towards the end of the "golden age" (1962-1980), during which Latin America exhibited the most sustained, though not the most intensive, investment effort in its history.

For reasons of space, it is outside the scope of this work to analyse the nature of the movements in the series in greater depth. Yet there is one highly idiosyncratic component of the macromagnitude examined which should not be overlooked: its great variability. The data in table 6 show clearly that investment has fluctuated strongly. The measure of volatility far exceeded the annual growth rate in all the cycles. The only two exceptions to this pattern occurred at the time of the largest boom, during the shield of State intervention (from 1952 to 1958 and from 1962 to 1980). But the prime focus of attention must be the fact that in the century prior to 1950 , standard deviation was five times the rate of annual variation, which speaks of an extremely volatile variable. By contrast, since 1950 the investment cycle has become much less extreme (standard deviation is only 50\% more than the growth rate). The most severe cycle by far was during the First World War, when there was an extreme swing between the most violent contractionary and expansionary phases in the last century and a half. The cycles of 1884-1890, 1890-1896 and 1929-1937 were also turbulent, with large expansions and reactivations before and after major slumps. Conversely, the expansionary cycle at the end of the belle époque (1907-1913) was characterized by a very stable rate of growth. No doubt the mythical aura surrounding this period has much to do with that regularity. Interestingly, the same cannot be said of the other period often thought to be the most prosperous before the "golden age": the 1920s.

\section{V \\ Concluding remarks}

Empirical studies on the theory of economic growth are limited by a lack of statistical data on the basic macromagnitudes of developing economies in the period before 1950. In the case of the Latin American countries, data on capital formation were particularly lacking. This work has to a great extent covered that deficit by providing a quantification of GFCF and its two main components -investment in equipment and in construction - for all the countries of the region, except Guatemala, Panama and Paraguay. The annual and continuous series provided span the period from 1856 to 1950. Linking these series with those generated by the official national accounts systematized and standardized by ECLAC provides a reliable quantification of GFCF in the Latin American economies from 1856 to the present.

Several important facts emerge from the examination of very long-term GFCF patterns. First, the greatest investment growth occurred in the second half of the nineteenth century, during the first wave of globalization; more specifically, between 1856 (possibly earlier) and
1890. Second, it was over this period, not later, that equipment endowment grew faster than endowments of other capital goods, which means that the region's economies boosted their long-term growth potential more in the nineteenth century than they did later, or at least during the first half of the twentieth century. Third, GFCF was highly volatile during the century leading up to 1950 , becoming much less so thereafter. The explanation for the contrast probably lies in the key impact of primary goods exports and foreign capital on GFCF before the Second World War. Insofar as investment instability is bad for economic growth, the possibilities for Latin American economies have brightened since the Second World War. Fourth and last, the data show that the most laggard economies have tended to make a greater investment effort per capita than more advanced economies. This has produced only very partial convergence, however: the disparities in per capita investment levels, which were extreme in the mid-nineteenth century, have remained very sharp. 


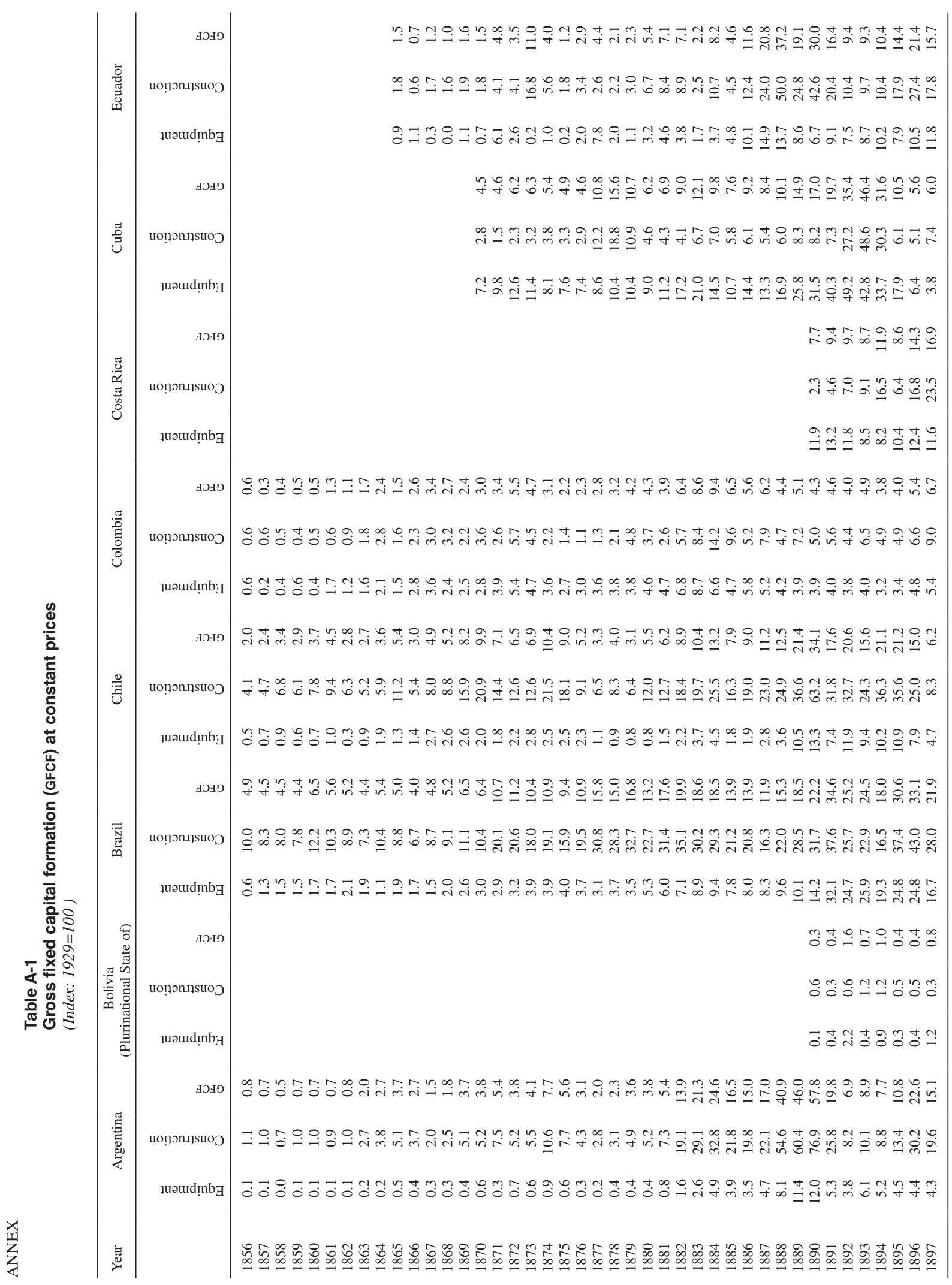




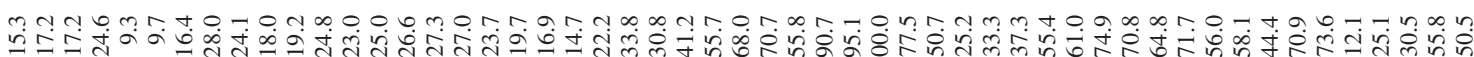

䔍

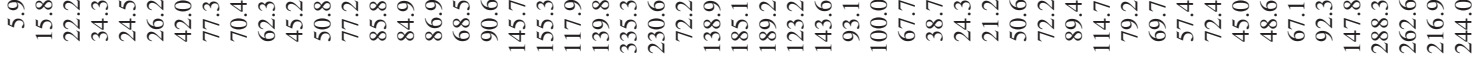

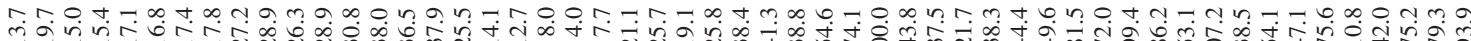

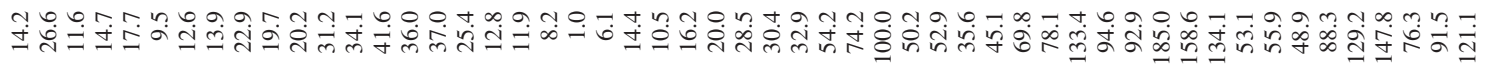

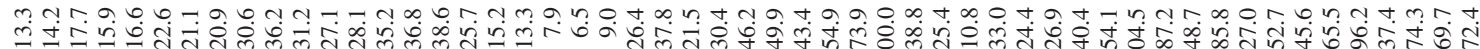
tomino

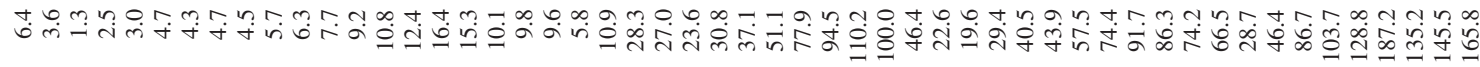

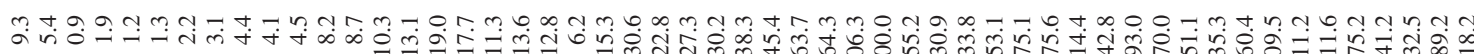
-

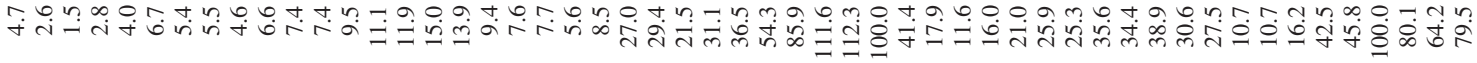

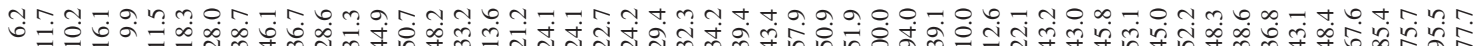

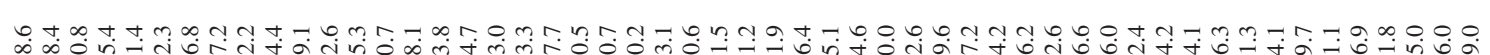
+

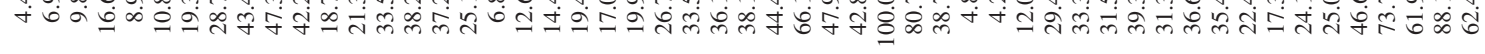

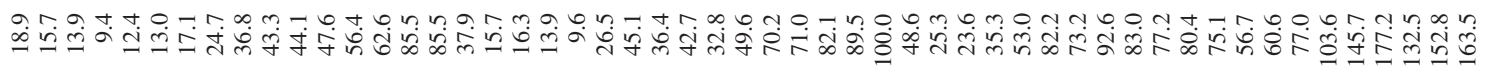

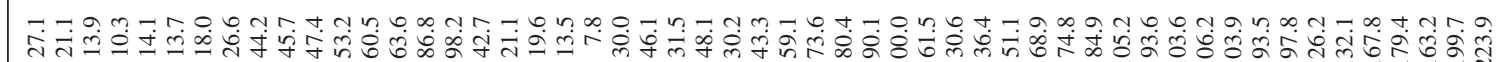
0 -

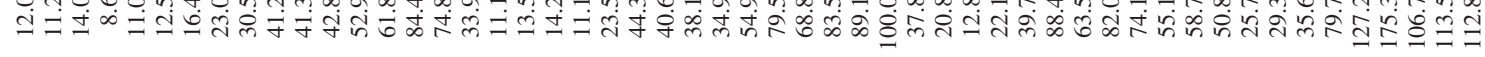

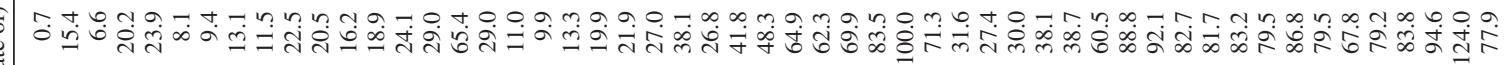

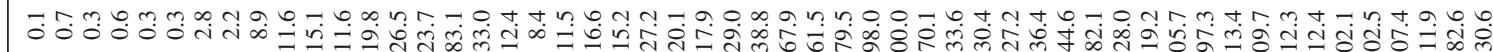

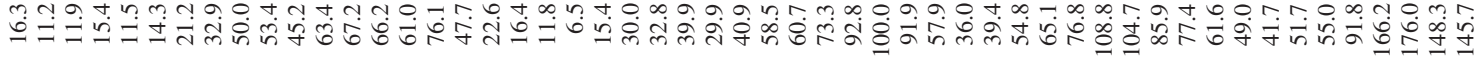

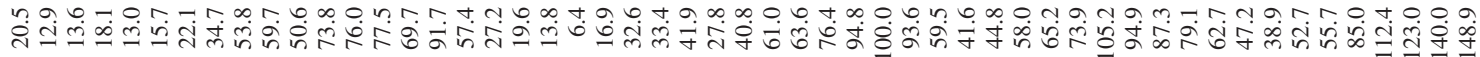

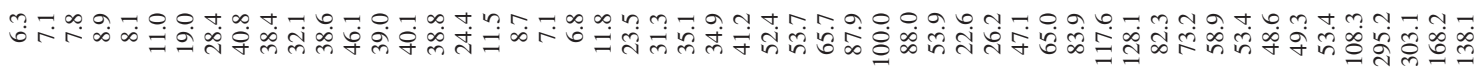
范 


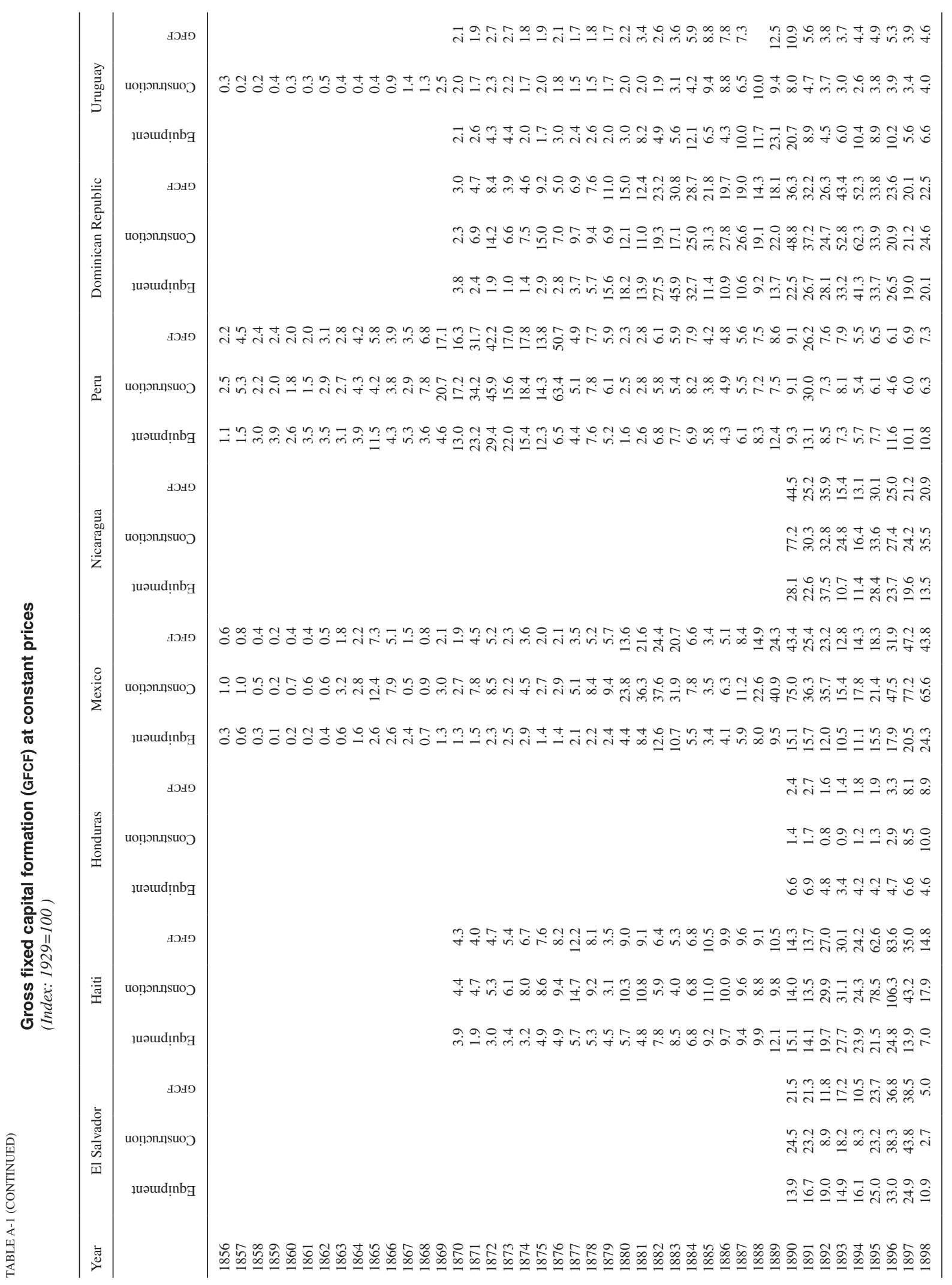




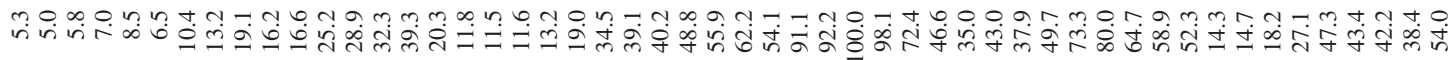

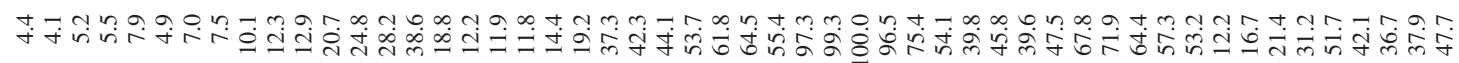

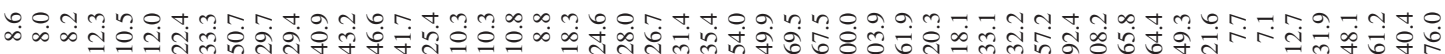

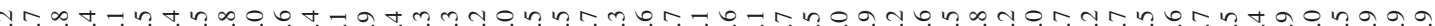

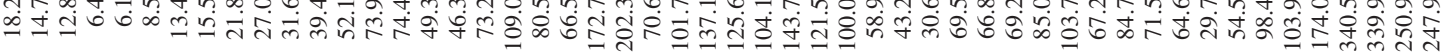
gmingm-maminaGn

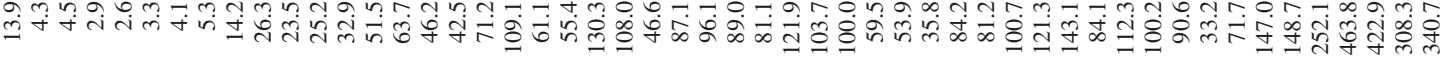

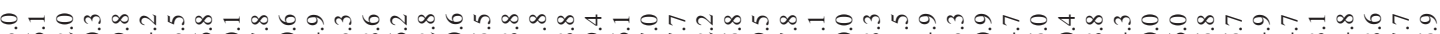

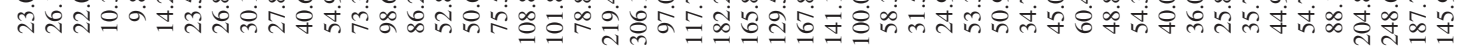
- $6 \infty$ t

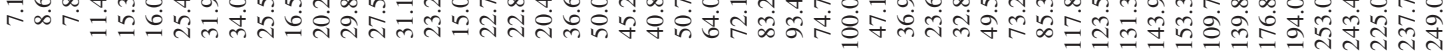

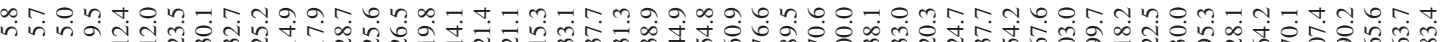

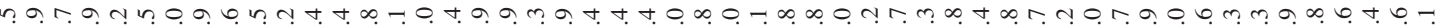

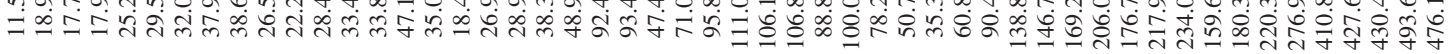

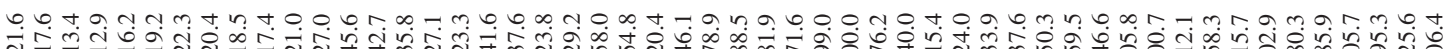

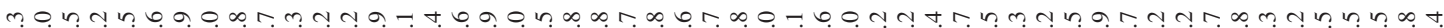

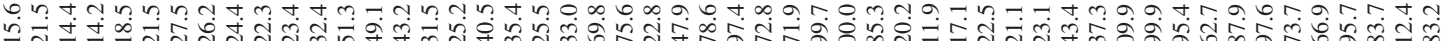

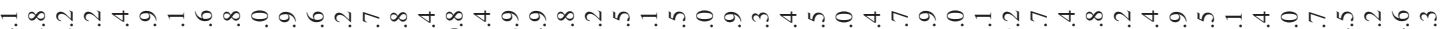
宊

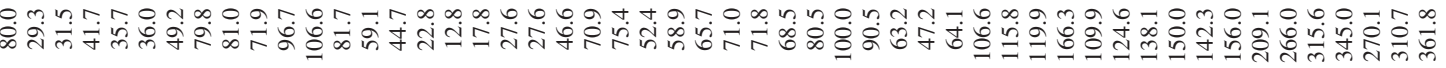

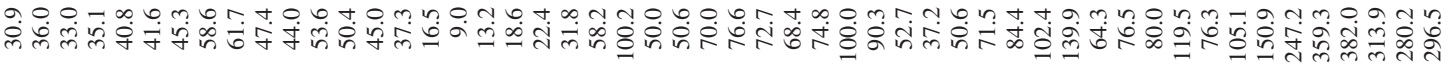

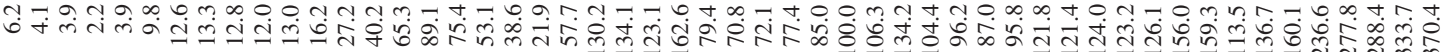

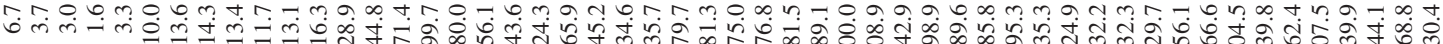

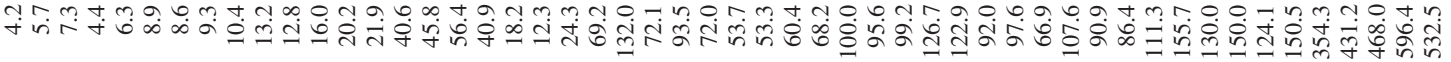

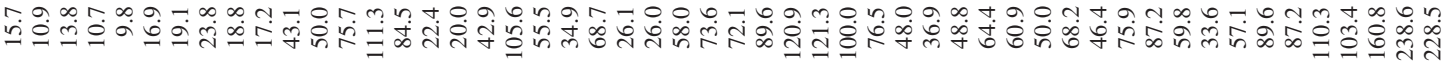

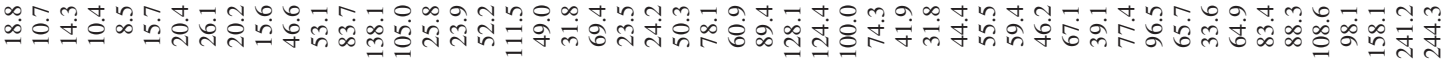
我设 1

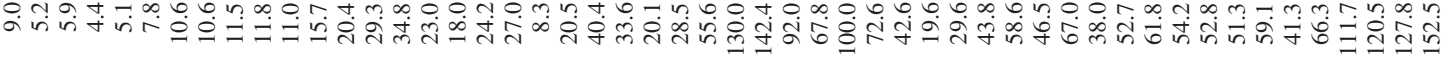

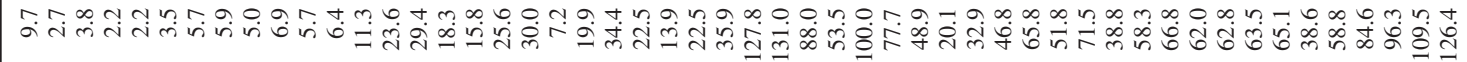
m

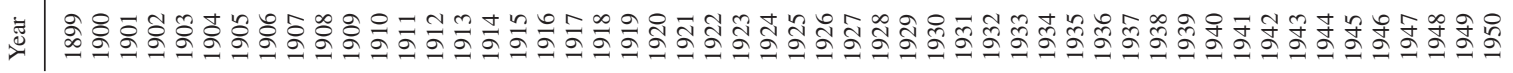




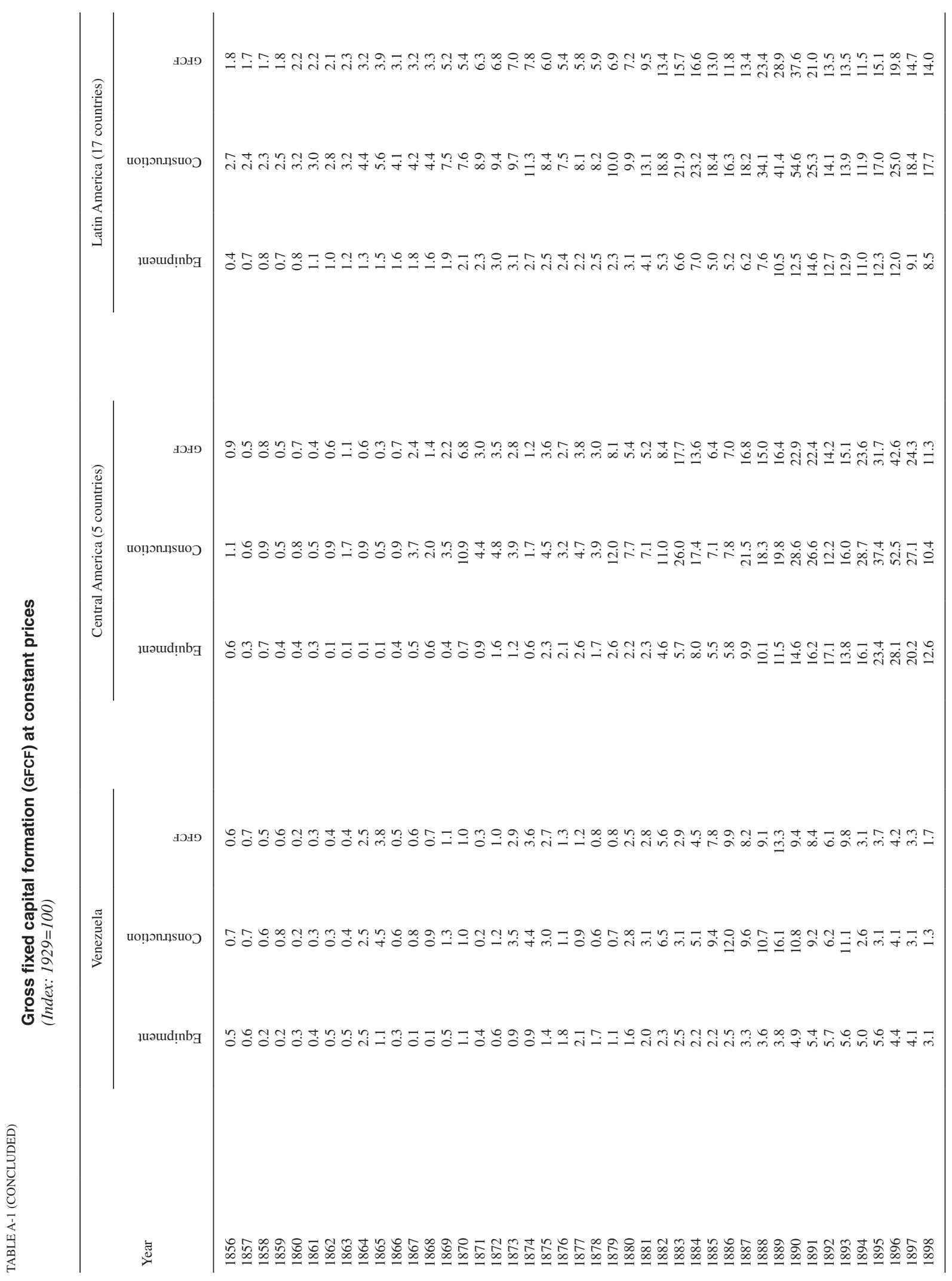




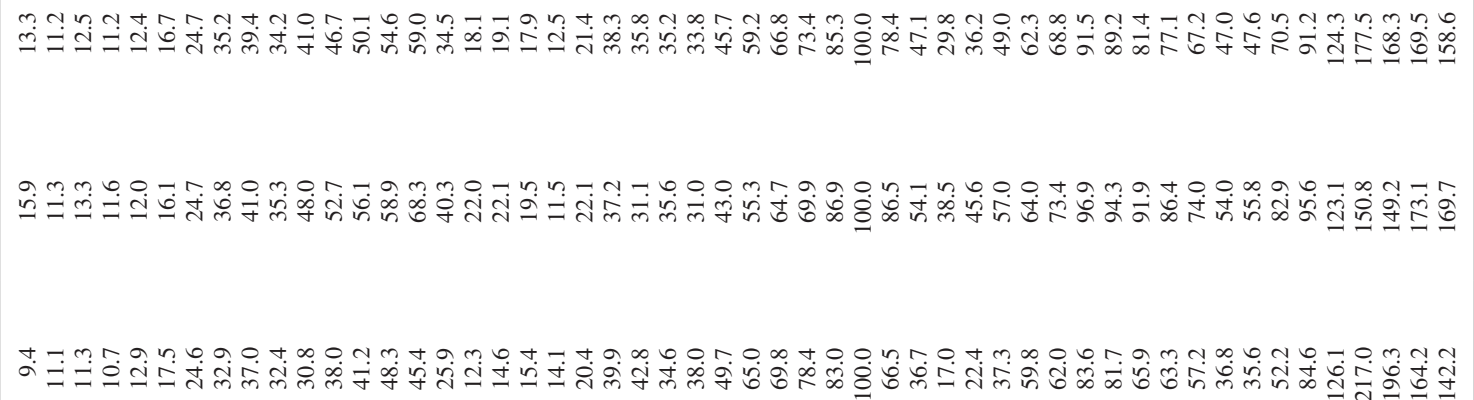

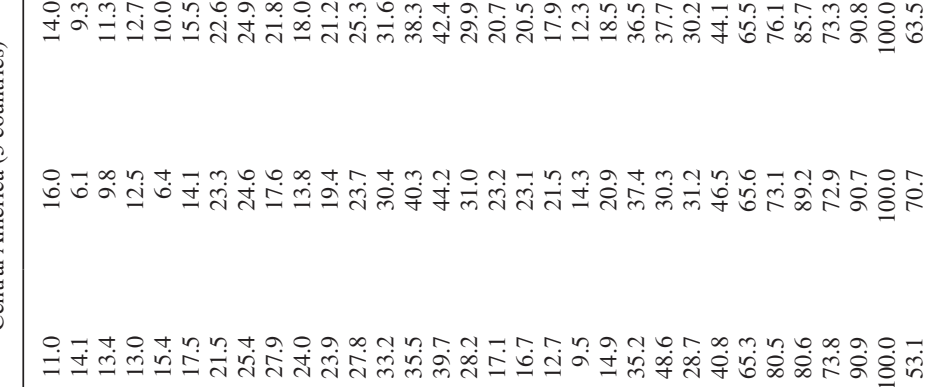

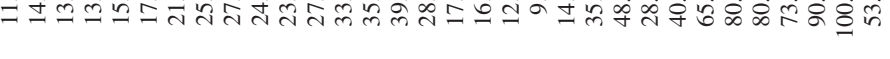

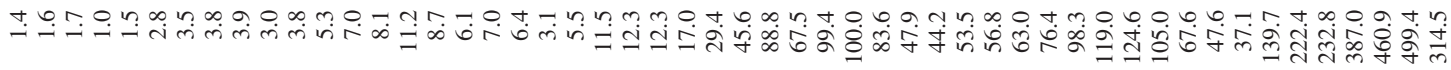

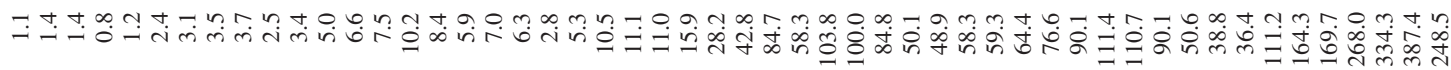

तิ

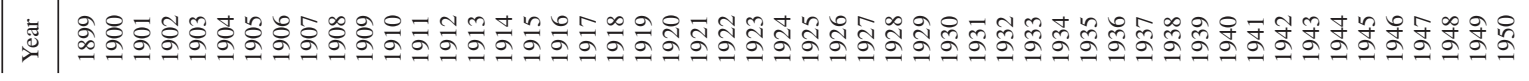


Abu-Qarn, Aamer S. and Suleiman Abu-Bader (2007), "Sources of growth revisited: evidence from selected MENA countries", World Development, vol. 35, No. 5, Amsterdam, Elsevier.

Bértola, Luis (1998), El PBI uruguayo 1870-1936 y otras estimaciones, Montevideo, University of the Republic.

Bértola, Luis and José Antonio Ocampo (2010), Desarrollo, vaivenes y desigualdad. Una historia económica de América Latina desde la Independencia, Madrid, Ibero-American General Secretariat.

Bosworth, Barry P. and Susan M. Collins (2008), "Accounting for growth: comparing China and India", Journal of Economic Perspectives, vol. 22, No. 1, Nashville, Tennessee, American Economic Association.

(2003), “The empirics of growth: an update", Brookings Papers in Economic Activity, vol. 34, No. 2, Washington, D.C., The Brookings Institution.

Bulmer-Thomas, V., J.H. Coatsworth and R. Cortés Conde (eds.) (2006), "The long Twentieth Century", The Cambridge Economic History of Latin America, vol. 2, Cambridge, Cambridge University Press.

Collins, Susan M. and Barry P. Bosworth (1996), "Economic growth in East Asia: accumulation versus assimilation", Brooking Papers on Economic Activity, vol. 1996, No. 2, Washington, D.C., Brookings Institution Press.

Deas, Malcolm (2010), "Inseguridad y desarrollo económico en Colombia en el primer siglo de vida republicana independiente: Unas consideraciones preliminares", Economía colombiana del siglo XIX, Adolfo Meisel and María Teresa Ramírez (eds.), Bogota, Bank of the Republic.

Ducoing, Christián A. (2012), Inversión en maquinaria, productividad del capital y crecimiento económico en el largo plazo. Chile 1830-1938, Ph.D. thesis, Barcelona, University of Barcelona.

Dye, Alan (2006), "The institutional framework", The Cambridge Economic History of Latin America, vol. 2, V. Bulmer-Thomas, J.H. Coatsworth and R. Cortés Conde (eds.), Cambridge, Cambridge University Press.

ECLAC (Economic Commission for Latin America and the Caribbean) (1951), Economic Survey of Latin America 1949 (E/CN.12/164/ Rev.1), New York, United Nations.

Elias, V.J. (1992), Sources of Growth: A Study of Seven Latin American Economies, San Francisco, Ics Press.

Fukuda, Shin-ichi and Hideki Toya (1998), "A new view on the source of East Asian economic growth: what made capital accumulation so remarkable in East Asia?", CIRJE F-36, Tokyo, Faculty of Economics, University of Tokyo.

Guajardo, Guillermo S. (1998), "Nuevos datos para un viejo debate: Los vínculos entre ferrocarriles e industrialización en Chile y México (1860-1950)", El trimestre económico, vol. 65, No. 258, Mexico City, Fondo de Cultura Económica. (1996), "Hecho en México: El eslabonamiento industrial 'hacia atrás' de los ferrocarriles, 1890-1950", Ferrocarriles y vida económica en México (1850-1950). Del surgimiento tardío al decaimiento precoz, Sandra Kuntz Ficker and Paolo Riguzzi (coords.), Zinacantepec, México, El Colegio Mexiquense.

Hofman, André (2000), The Economic Development of Latin America in the Twentieth Century, Cheltenham, Edward Elgar.

Kendrik, John W. (1993), "How much does capital explain?", Explaining Economic Growth. Essays in Honour of Angus Maddison, A. Szirmai, B. Van Ark and D. Pilat (eds.), Amsterdam, North-Holland.
Kim, Jong-Il and Lawrence Lau (1994), "The sources of economic growth of the East Asian newly industrialized countries", Journal of the Japanese and International Economics, vol. 8, No. 3, Amsterdam, Elsevier.

Krugman, Paul (1994), "The myth of Asia's miracle", Foreign Affairs, vol. 73 , No. 6.

Levine, Ross and David Renelt (1992), "A sensitivity analysis of crosscountry growth regressions", American Economic Review, vol. 82, No. 4, Nashville, Tennessee, American Economic Association.

Loayza, Norman, Pablo Fajnzylber and César Calderón (2005), Economic Growth in Latin America and the Caribbean: Stylized Facts, Explanations, and Forecasts, Washington, D.C., World Bank.

Maddison, Angus (2007), Contours of the World Economy, 1-2030 AD: Essays in Macroeconomic History, Oxford, Oxford University Press.

Marichal, Carlos (1989), A Century of Debt Crises in Latin America, 1820-1930, Princeton, Princeton University Press.

Mitchener, Kris James and Marc D. Weidenmier (2008), "The Baring crisis and the great Latin American meltdown of the 1890s", Journal of Economic History, vol. 68, No. 2, Cambridge University Press.

Ocampo, José Antonio (2004), "La América Latina y la economía mundial en el largo siglo XX", El trimestre económico, vol. 71, No. 284, Mexico City, Fondo de Cultura Económica.

Prados de la Escosura, Leandro (2003), El progreso económico de España (1850-2000), Madrid, BBVA Foundation.

Qi, Liangshu (2007), "The relationship between growth, total investment and inward FDI: evidence from time series data", International Review of Applied Economics, vol. 21, No. 1, Taylor \& Francis.

Sala-i-Martín, Xavier (1997), "I just ran two million regressions", American Economic Review, vol. 87, No. 2, Nashville, Tennessee, American Economic Association.

Tafunell, Xavier (2011), "Un siglo de formación de capital en América Latina (1856-1950). Ensayo de cuantificación general”, paper presented at the $\mathrm{X}$ International Congress of the Spanish Association for Economic History (Carmona, Spain, 7-9 September).

(2009a), "Capital formation in machinery in Latin America 1890-1930", Journal of Economic History, vol. 69, No. 4, Cambridge University Press.

(2009b), "La inversión en equipo de transporte de América Latina, 1890-1930: una estimación basada en la demanda de importaciones", Investigaciones de historia económica, vol. 5 , No. 14, Amsterdam, Elsevier.

(2007), "On the origins of ISI: the Latin American cement industry, 1900-1930", Journal of Latin American Studies, vol. 39, No. 2, Cambridge University Press.

Temple, Jonathan and Hans-Joachim Voth (1998), "Human capital, equipment investment, and industrialization", European Economic Review, vol. 42, No. 7, Amsterdam, Elsevier.

Young, Alwyn (1995), "The tyranny of numbers: confronting the statistical realities of the East Asia growth experience", Quarterly Journal of Economics, vol. 110, No. 3, Oxford University Press. (1994), "Lessons from the East Asian Nics: a contrarian view", European Economic Review, vol. 38, No. 3-4, Amsterdam, Elsevier. 